\title{
The Use of Structural Equation Model (SEM) to Evaluate the Effectiveness of ISO 9001 Quality Management System (QMS) on the Performance of Oil and Gas Drilling Companies
}

\author{
Ali M. Harthy ${ }^{1}$, Neelufer Aslam², Said M. Al Saqri ${ }^{3}$, Siti Arni ${ }^{4}$, Sulo Nair ${ }^{5} \&$ Asif M. Karim ${ }^{5}$ \\ ${ }^{1}$ Wells Business Planning, Petroleum Development Oman (PDO), Oman \\ ${ }^{2}$ Waljat College of Applied Sciences, Oman \\ ${ }^{3}$ Corporate environment advisor, Petroleum Development Oman (PDO), Oman \\ ${ }^{4}$ University of Malaya, Malaysia \\ ${ }^{5}$ Binary University, Malaysia \\ Correspondence: Ali Malik Al Harthi, Wells Business Planning, Petroleum Development Oman (PDO), Oman. \\ E-mail: ali.m.harthy@pdo.co.om
}

Received: November 17, 2019

Accepted: December 2, 2019 Online Published: December 12, 2019

doi:10.5539/ijbm.v15n1p59

URL: https://doi.org/10.5539/ijbm.v15n1p59

\begin{abstract}
The purpose of this paper is to evaluate the effectiveness of ISO9001 through achieving its intended objectives and determine its impact on the performance dimensions of oil and gas drilling companies which are related to operations and HSE. 375 samples were obtained using a structured questionnaire from oil and gas drilling companies operating in OMAN to conduct an empirical study. A structured equation modeling (SEM) through SMART PLS was applied in order to determine the impact of ISO 9001 effectiveness on the performance dimensions of oil and gas drilling companies. The findings of this study reveal as identified in the literature, the dimensions of the ISO 9001 effectiveness which are evaluated by the degree of achievement of the standard's objectives, namely (continuous improvement, customer focus, prevention of nonconformities, risk-based thinking, leadership \& commitment and Competency framework) and reveals its significant contribution to the performance of the oil and gas drilling companies. The operational and HSE performance of the oil and gas drilling companies are directly and significantly influenced by ISO 9001 effectiveness. The findings of this study revealed that the R2 value for the first order constructs which are the six ISO objectives are all above the 0.7 , implying that the six constructs significantly explain the second order construct ISO 9001 QMS effectiveness. The $\mathrm{R}^{2}$ for QMS effectiveness is 0.460 which means that, $46 \%$ of the variation in performance can be explained by effective quality management systems. The effect size $\mathrm{f}^{2}$ was calculated to assess the effect each latent construct has on Quality Management Systems. It has been revealed in this study that PNC has the highest effect on QMS followed by CI, RBT, L\&C, CF and CFW respectively. From the Q square statistic, it is inferred that QMS 9001 effectiveness has a high (strong) effect of $39 \%$ on performance. Finally, the Model fit was assessed based on the SRMR criteria by which it revealed a good fit of the model which was 0.052 . These findings will support practitioners and decision makers to focus on quality related problems that might occur in their current or future projects to enhance their organization performance.
\end{abstract}

Keywords: Oman, oil and gas industry, drilling companies, ISO 9001 effectiveness, ISO 9001 objectives, performance, QMS, SEM-PLS, conceptual framework.

\section{Introduction}

In general, the world economy depends on the service sector (Lee, 2009). Oil and Gas industry is one of the most critical service sectors by which it contributes the most, in the economy of majority of countries around the world, (Donwa, 2015). One of the sectors in oil and gas industry is the upstream sector which also known as the exploration and production (E\&P) such as drilling and work over activities (Perrons, 2013), which are executed by drilling rigs. Drilling rigs are mainly defined as massive structure hoisting equipment used to drill well bore which can be water wells, oil wells or natural gas wells with an overall objective to produce Oil and Gas (Robinson, 2015). These drilling rigs can drill wells On-Shore whereby the drilling unit will be allocated on the land or drill 
wells Off-Shore by which the rigs will be allocated on the sea (IADC, 2015).

The current markets demand that the oil and gas drilling companies shall establish and implement QMS according to internationally accredited management standard such as ISO 9001 (Karapetrovic, 1998). In addition, drilling companies should continually improve the effectiveness of their quality management systems (QMS), Marin (2011) to enhance their performance. In fact, having QMS is simply a requirement to do business in this sector, (Gomez, 2011). For example, there is a mandatory clause in all oil and gas drilling tenders in OMAN for the bidders to be an ISO (International Organization for Standardization) 9001 (QMS) certified company, with an overall objective to enhance their performance.

However, previous studies supported that only obtaining and preserving the ISO 9001 certificate is not enough, (Lee, 2011) and fulfilling and conforming to a quality standard's minimal requirements by itself is insufficient. Nowadays, the main competitive edge shifts from simply applying the ISO 9001 standard to successfully implementing an effective quality management system (QMS) after obtaining the certification. Hence, if the drilling companies aim to achieve their targeted performance and higher results, the accomplishment of a quality certificate to ISO 9001 should not be the end, but the starting point for deploying an effective QMS in the quest for quality improvement.

Despite oil and gas drilling companies operating in OMAN are having ISO9001. However, it is not reflected in their performance which is indicated by two critical aspects namely: Health, Safety and Environment (HSE) performance through recordable trend and Operational performance through Non-Productive Timing (NPT) trend. Thus, and given the contradictory nature regarding the successful implementation and contribution of ISO 9001 to company performance, more fact-based and statistically oriented studies in the area of the ISO 9001 QMS are required. Accordingly, Augustyn and Pheby, Yaya et al. and To et al. specifically highlight the need for further contextual research for the impact of ISO 9001 on performance in several service sub-sectors. In addition, examining how the depth of ISO 9001 implementation influences company performance in the long run has been suggested by Jang and Lin and Sampaio et al.

A company having established a QMS according to ISO 9001 should test the standard's effectiveness by evaluating the degree to which its pre-established objectives and expectations are achieved. Defining for the first time in the oil and gas sector ISO 9001 effectiveness as the achievement of ISO 9001 objectives, the purpose of the present study is twofold: first is to evaluate the validity of ISO 9001 QMS effectiveness model, by providing empirical evidence from the oil and gas sector. Second to that is to highlight the impact of ISO 9001 effectiveness on the oil and gas drilling companies' performance (e.g performance dimensions are defined as HSE and operational performance).

By exploring ISO 9001 effectiveness patterns and performance outcomes in oil and gas organizations, this study provides new and practically relevant insights into the literature. Data from large oil and gas drilling companies were obtained and analyzed using Structural Equation Modeling-Partial Least Squares method which is addressing recent studies limitation. For example, according to Pozma (2012), due to the small sample size, the relationships between ISO 9001 effectiveness and the performance dimensions of service companies are determined through multiple linear regression analyses that are applied separately. Consequently, the structural equation modeling (SEM) technique, that allows the concurrent determination of the relationships among several factors, cannot be applied due to sample size restrictions. Thus, future research studies should be conducted based on a larger sample of service companies to which the SEM technique can be applied. In doing so, the statistically significant differences among small-, medium- and large-sized companies can also be detected (regarding ISO 9001 effectiveness and company performance).

The rest of the paper is structured as follows: in the first part, the literature is reviewed in order to precisely define ISO 9001 effectiveness and specific company performance dimensions. In the next part, the methodology of the research study is described which is followed by the data analysis and the respective results. Then, the results are discussed including conclusion and recommendations for oil and gas drilling companies.

\section{Literature Review}

\subsection{ISO 9001 Effectiveness}

According to the ISO 9001 standard, "effectiveness" is defined as the extent to which the anticipated objectives are achieved (ISO 9001:2000, 2000) namely: Customer focus, Continual Improvement and prevention of non-conformance. In addition, many studies which were conducted in QMS confirmed and validated that the three main ISO9001 Objectives which will determine its effectiveness.

However, those studies were based on the older versions of ISO9001:2008 and older versions of ISO standards 
which were designed to be process based approach (ISO9001:2008, 2008). In 2015, ISO released the new version of ISO9001: 2015 which is considered to be a risk-based approach (ISO9001:2015, 2015) and this is the forth objective of ISO9001. In addition, two extra objectives of ISO9001 were derived from previous studies including Ahmed -2016, Todorust-2012, Zwain-2012 and Umar-2004 namely leadership \& commitment and competency framework.

The six ISO 9001 objectives identified in the literature namely (prevention of nonconformities, continuous improvement, customer satisfaction, risk based thinking, leadership \& commitment and competency framework) that define ISO 9001 effectiveness was further verified and confirmed using a sample of large oil and gas drilling companies and objective data that was drawn from the actual documents of ISO 9001 from oil and gas drilling companies. Table one summarizes ISO 9001 objectives which achieves its effectiveness by different studies in different industries.

Table 1. Comparing the measurement instrument developed in the present study with those of similar studies

\begin{tabular}{|c|c|c|}
\hline Study & Purpose & $\begin{array}{l}\text { Measures on which the study is based - ISO } \\
\text { Objectives }\end{array}$ \\
\hline Present Study & $\begin{array}{l}\text { To evaluate of QMS ISO } 9001 \text { effectiveness on the performance } \\
\text { of oil \& gas drilling sector }\end{array}$ & $\begin{array}{l}\text { 1.Continuous improvement } \\
\text { 2. Prevention of nonconformities } \\
\text { 3. Customer satisfaction focus } \\
\text { 4. Risk based thinking } \\
\text { 5. Leadership and commitment } \\
\text { 6. Competency framework }\end{array}$ \\
\hline $\begin{array}{l}\text { Evangelos L } \\
(2011,2012) \\
\text { Martinez-Costa et al., } \\
(2009)\end{array}$ & $\begin{array}{l}\text { The impact of ISO } 9001 \text { effectiveness on the performance \& } \\
\text { The development of an instrument for measuring the } \\
\text { effectiveness of ISO 9001in food manufacturing SMEs }\end{array}$ & $\begin{array}{l}\text { 1.Continuous improvement } \\
\text { 2.Prevention of nonconformities } \\
\text { 3.Customer satisfaction focus }\end{array}$ \\
\hline $\begin{array}{l}\text { Jang and } \\
\text { Lin (2008) }\end{array}$ & $\begin{array}{l}\text { The measurement of the long-term effectiveness and the real } \\
\text { value of ISO } 9001\end{array}$ & $\begin{array}{l}\text { 1.Standard procedures and documentation } \\
\text { 2.Top management support and Training } \\
\text { 3.Periodic auditing and corrective action }\end{array}$ \\
\hline $\begin{array}{l}\text { Oztas et al.\& } \\
\text { van der Spiegel } \\
(2007)\end{array}$ & The measurement of the effectiveness of ISO 9001 & $\begin{array}{l}\text { 1.Continual improvement } \\
\text { 2.Customer satisfaction }\end{array}$ \\
\hline $\begin{array}{l}\text { Van der Spiegel et al. } \\
(2007,2005) \\
\text { Gotzamani/ Goetsch and } \\
\text { Davis/Briscoe et al. (2005) } \\
\text { Tsim et al. (2002) }\end{array}$ & $\begin{array}{l}\text { The development of an instrument that measures the } \\
\text { effectiveness of food quality systems implemented as an } \\
\text { integrated system }\end{array}$ & $\begin{array}{l}\text { 1.Contextual factors (the complexity of the } \\
\text { organization, the production process, and } \\
\text { product assortment) } \\
\text { 2.Continual improvement which lead to } \\
\text { customer focus. } \\
\text { 3.Customer and regulatory requirements } \\
\text { compliance }\end{array}$ \\
\hline $\begin{array}{l}\text { Al-Nakeeb } \\
\text { et al. (1998) }\end{array}$ & The investigation of the effectiveness of the ISO $9001 \mathrm{QMS}$ & $\begin{array}{l}\text { 1.Customer needs and expectations } \\
\text { 2.Customer satisfaction }\end{array}$ \\
\hline $\begin{array}{l}\text { De Toni } \\
\text { et al. (1995) }\end{array}$ & $\begin{array}{l}\text { The evaluation of the quality performance measurement level } \\
\text { and the quality performance results }\end{array}$ & $\begin{array}{l}\text { 1.Total quality } \\
\text { 2.Perceived quality and customer } \\
\text { satisfaction. } \\
\text { 3.Quality cost }\end{array}$ \\
\hline
\end{tabular}

In addition, the indicators for the assessment of these six ISO objectives are drawn from the study of (Ali, 2018) supported by literature review as summarized in Table two. 
Table 2. The indicators of the ISO 9001 objectives

\begin{tabular}{|c|c|c|}
\hline \multicolumn{3}{|c|}{ Supporting Literature } \\
\hline \multirow{7}{*}{ 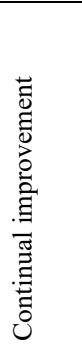 } & Development of CI Business & Singh et al. (2006), Brah et al. (2002), Zhang et al. (2000), Archie Lockamy, 2004, Hashem \\
\hline & Plan & Salarzadeh Jenatabadi, 2013, Ndegwa, Caroline W., 2017, SIMON KIPLANGAT, 2016, Sophia \\
\hline & & W. Muriuki, 2010 \\
\hline & Documentation review and & Kumar et al. (2011), Sadikoglu and Zehir (2010), Psomas et al. (2011), Psomas and Fotopoulos \\
\hline & Update & (2010), Conca et al. (2004), Claver et al. (2002) \\
\hline & Process Simplicity & $\begin{array}{l}\text { Manabu Kano (2008), Jacob A.Moulijn (2007), Dong-YoungKim, 2012, J. C. A. M. Buijs, 2014, } \\
\text { Junho H.Choi, 2012, D. L. Andress, } 2004\end{array}$ \\
\hline & Visual Management & $\begin{array}{l}\text { Singh et al. (2006), Seth and Tripathi (2005), Su et al. (2003), Dong-YoungKim, 2012, G. C. } \\
\text { Parry, 2007, Emma Bell and Jane Davison in 2012, Tezel, BA, Koskela, LJ and Tzortzopoulos in } \\
2009\end{array}$ \\
\hline $\begin{array}{l}\ddot{\#} \\
\ddot{Z}\end{array}$ & Opportunities identification & $\begin{array}{l}\text { Fotopoulos and Psomas (2010), Psomas and Fotopoulos (2010), Singh et al. (2006), Conca et al. } \\
\text { (2004), Claver et al. (2002), Dong-YoungKim, } 2012\end{array}$ \\
\hline \multirow{6}{*}{ 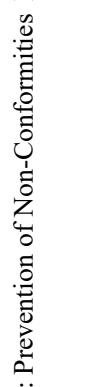 } & Process conformity & $\begin{array}{l}\text { Singh (2008), Brad (2008), Chileshe (2007), Marin and Ruiz-Olalla (2011), Kathuria et al. } \\
\text { (2010), Avella and Vazquez-Bustelo (2010), Chi et al. (2009), van der Spiegel et al. (2005), } \\
\text { Kathuria (2000), Psomas et al. (2011), Lewis et al. (2006), Fatimah Zulfah S. Padmadinata in } \\
\text { 2007, Manabu Kano (2008) }\end{array}$ \\
\hline & Effective QA/QC & Chiarini (2011), Singh (2008), Marin and Ruiz-Olalla (2011), Kathuria et al. (2010), Avella and \\
\hline & & Vazquez-Bustelo (2010), Chi et al. (2009), van der Spiegel et al. (2005), Kathuria (2000), van der \\
\hline & & Spiegel et al. (2005, 2007), James C. Fuscoe, 2007 \\
\hline & Preventative Maintenance & $\begin{array}{l}\text { Low and Abeyegoonasekera (2001), Ofori, Gang and Briffett (2002), DF Barbian in 2007, } \\
\text { F.T.S.Chan, 2005, Kathleen EMcKone, } 2001\end{array}$ \\
\hline & Corrective action & $\begin{array}{l}\text { Farooqui and Ahmed (2009), Lordsleem, Duarte and Barkokébas (2010), Heinrich Mintrop, } \\
\text { 2005, Duke Okes, } 2017\end{array}$ \\
\hline \multirow[t]{4}{*}{$\begin{array}{l}\ddot{\#} \\
\gtrless\end{array}$} & $\begin{array}{l}\text { Comply with legal and other } \\
\text { requirements }\end{array}$ & Leonard (2010), Watson and Howarth (2011), ISO9001(2015), OPAL (2017) \\
\hline & $\begin{array}{l}\text { Define customer/ interested } \\
\text { parties }\end{array}$ & Samson and Mile (1999), Barbara B.Flynn and Roger G.Schroeder in 1994. \\
\hline & Understand their needs & $\begin{array}{l}\text { Kumar et al. (2011), Sadikoglu and Zehir (2010), Singh (2008), Jayamaha et al. (2008), Lam et } \\
\text { al. }\end{array}$ \\
\hline & & (2008), Sharma and Kodali (2008), Chileshe (2007), Lewis et al. (2006), Barbara B.Flynn and \\
\hline \multirow{4}{*}{ 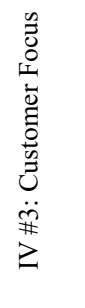 } & $\begin{array}{l}\text { Customer } \quad \text { feedback } \\
\text { measurement }\end{array}$ & $\begin{array}{l}\text { Anh and Matsui (2011), Mady (2009), Das et al. (2008), Jayamaha et al. (2008), Lam et al. } \\
\text { (2008), Sharma and Kodali (2008), Shepherd and Gunter (2005), Barbara B.Flynn and Roger } \\
\text { G.Schroeder in } 1994 .\end{array}$ \\
\hline & $\begin{array}{l}\text { Plan \& control to address } \\
\text { customer needs. }\end{array}$ & $\begin{array}{l}\text { Chiarini (2011), Kim et al. (2011), Anh and Matsui (2011), Mady (2009), Brad (2008), Das et al. } \\
\text { (2008), Fening et al. (2008), Ooi et al. (2008), Phusavat and Kanchana (2008) }\end{array}$ \\
\hline & Effective Communication & $\begin{array}{l}\text { Barbara B.Flynn and Roger G.Schroeder in 1994, M. Sajid Khattak \& Amanat Ali (2000), } \\
\text { OrhanÇömlek, 2012, Junho H.Choi, 2012, J. Randall Curtis, } 2013\end{array}$ \\
\hline & Risk assessment & $\begin{array}{l}\text { VCarr, 2001, Julian C.Sweeney, 1999, Marcelo VinhalNepomuceno, 2014, S. BARBAR and } \\
\text { F.noventa in } 2010\end{array}$ \\
\hline \multirow{5}{*}{ 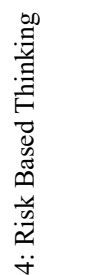 } & Audits at different levels & $\begin{array}{l}\text { Alic and Rusjan (2010, 2011), Singh (2008), Ramnauth et al. (2008), Brad (2008), Das et al. } \\
\text { (2008) }\end{array}$ \\
\hline & MOC & Peter andSohal (2016), Peer C. Fiss and Edward J. Zajac, (2017), SIMON KIPLANGAT, 2016 \\
\hline & Communication & K.T.Beyene, 2016, M. Sajid Khattak \& Amanat Ali (2000), OrhanÇömlek, 2012, \\
\hline & Opportunities identification & Fotopoulos and Psomas (2010), Psomas and \\
\hline & & Fotopoulos (2010), Singh et al. (2006), Conca et al.(2004), Claver et al. (2002) \\
\hline \multirow{5}{*}{ 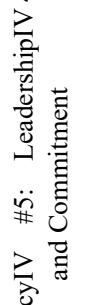 } & Policy \& Objective set up & $\begin{array}{l}\text { Singh et al. (2006), Tsim et al. (2002), Zhang et al. (2000), Chileshe (2007), Barbara B.Flynn and } \\
\text { Roger G.Schroeder in 1994, SIMON KIPLANGAT, 2016, Sophia W. Muriuki, } 2010\end{array}$ \\
\hline & Participation \& involvement & $\begin{array}{l}\text { Kim et al. (2011), Sadikoglu and Zehir (2010), Singh (2008), Sharma and Kodali (2008), Singh } \\
\text { et al. (2006), Sun et al. (2004), Lawrence Makau, 2017, SIMON KIPLANGAT, } 2016\end{array}$ \\
\hline & Organization Structure setup & Marin-Garcia et al. (2008), Sharma and Kodali (2008), Conca et al. (2004) \\
\hline & Resource allocation & $\begin{array}{l}\text { Barbara B.Flynn and Roger G.Schroeder in 1994, M. Sajid Khattak \& Amanat Ali (2000), } \\
\text { OrhanÇömlek, 2012, Hashem Salarzadeh Jenatabadi, } 2013\end{array}$ \\
\hline & Awareness & OrhanÇömlek, 2012, C.H. Fang, S.T. Chang, G.L. Chen (2010), Henry De-Graft Acquah, 2011 \\
\hline \multirow{3}{*}{ 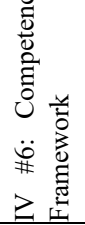 } & Skills and training & $\begin{array}{l}\text { J-J Rethans (2002), Dr. Amir Elnaga, 2013, Ahmad, Z.K. and Bakar, R.A. (2003), J. Randall } \\
\text { Curtis, } 2013\end{array}$ \\
\hline & Competency assessment & $\begin{array}{l}\text { Dingsdag et al. (2006), Margaret M. Heffernan, 2000, SIMON KIPLANGAT, } 2016 . \\
\text { J.J Rethans, 2002, Alec R.Levenson, } 2006\end{array}$ \\
\hline & Coaching & $\begin{array}{l}\text { Alec R.Levenson (2006), Ritu Agarwal , 2009, Fournies, Ferdinand F., 1987, J. Richard } \\
\text { Hackman and Ruth Wageman, } 2005\end{array}$ \\
\hline
\end{tabular}




\subsection{Company Performance Dimensions}

Effectiveness and efficiency of quality management implementation are important for improving performance of an organization. Many quality managements studies in the past studied the effects of different quality practices on the overall performance. The oil and gas performance dimensions for this study have been defined and divided into two categories namely: HSE performance and operational performance.

HSE performance is measured by the degree to which the general conditions of drilling activities promote the completion of well delivery without fatalities or injuries (Company $\mathrm{x}$, 2017). Drilling activities are known as one of the most dangerous and risky activities throughout the world as large amount of people are being killed and injured every year around the world (IADC, 2017). For this study, the HSE performance will be measured through recordable trends. Recordable trends are considered to be injuries or fatalities.

According to Johnston and Clark, 2001 operational performance refers to measurable aspects of the outcomes of an organization process such as reliability, production cycle time, and inventory turns. Terziovski, Feng and Samson, 2007 define operational performance as performance related to an organizational internal operation such as productivity, product quality and customer satisfaction. Hasan and Kerr, 2003 describe operational performance variables as productivity and quality, scheduling and delivery. Measures of productivity and quality are productivity, efficiency, cost of quality and errors and defects. Measures of scheduling and delivery are lead time, timeliness of delivery and vendor relations. Operational performance in this study will be measured through the percentage of non-productive timing for the drilling units. Table three will summaries the literature review to confirm the performance dimensions along with the indicators of the performance measurement.

Table 3. Comparing performance dimensions developed in the present study with those of similar studies

\begin{tabular}{|c|c|}
\hline Study & Measures on which the study is based \\
\hline Present Study & $\begin{array}{l}\text { Three performance-related dimensions have been chosen for the purpose of the present study: } \\
\text { 1.HSE Performance } \\
\text { 2.Operational Performance }\end{array}$ \\
\hline Tiong Kung Leong (2013) & $\begin{array}{l}\text { Using Project Performance to Measure Effectiveness of Quality Management System Maintenance } \\
\text { and Practices in Construction Industry, concluded that performance is measured by: } \\
\text { 1. Cost performance } \\
\text { 2. Time performance } \\
\text { 3. Quality performance } \\
\text { 4. Safety and health performance } \\
\text { 5. Clients' satisfaction }\end{array}$ \\
\hline $\begin{array}{l}\text { Evangelos L } \\
(2011,2012)\end{array}$ & $\begin{array}{l}\text { The impact of ISO } 9001 \text { effectiveness on the performance of a food manufacturing industry, } \\
\text { Performance measured by: } \\
\text { 1. Product/service quality } \\
\text { 2. Operational Performance } \\
\text { 3. Financial Performance }\end{array}$ \\
\hline Lee et al. (2009) & $\begin{array}{l}\text { Performance measures: } \\
\text { 1.customer satisfaction from service quality } \\
\text { 2.Cost of poor quality } \\
\text { 3.employee turnover rate }\end{array}$ \\
\hline A. Jusoh and S. M. Yatim, (2008) & $\begin{array}{l}\text { Measured performance by: } \\
\text { 1. Quality performance }\end{array}$ \\
\hline Singh et al. (2006) & $\begin{array}{l}\text { Benefits derived from implementing ISO } 9001 \& \text { measure performance by : } \\
\text { 1.Quality of customer service } \\
\text { 2.Documentation process } \\
\text { 3.Number of mistakes and defects }\end{array}$ \\
\hline Singh and Mansour-Nahra (2006) & $\begin{array}{l}\text { Conducted study in public sector organizations as a result of ISO } 9001 \text { implementation \& measures } \\
\text { performance by: } \\
\text { 1. Financial Improvement } \\
\text { 2. Operational efficiency }\end{array}$ \\
\hline McAdam and Canning (2001) & $\begin{array}{l}\text { Study the ISO } 9001 \text { benefits gained from small professional service firms related to } \\
\text { 1. Internal management system and communication. } \\
\text { 2. Service quality }\end{array}$ \\
\hline
\end{tabular}


Augustyn and Pheby (2000)

Tang and Kam (1999)

\section{Profit ratio}

Assess the potential impact of ISO 9001 implementation upon the performance of small tourism enterprises with regard to

1.customer complaints from service quality

2.Re-working, efficiency and error rate

3. Productivity and cost of lost orders including sales

conducting a survey on consulting firms, explore the benefits from implementing ISO 9001 \& measure performance by:

1. business operations

2. company's quality image

3. cost savings

D. Dow, D. Samson, and S. Ford Exploding the myth: do all quality management practices contribute to superior quality performance. (1999)

Measured performance by:

1.Quality performance

D. Samson and M. Terziovski (1999) The relationship between total quality management practices and operational performance. Measured performance by:

1. Operational performance

M. Y. Ismail and M. S. J. Hashmi The state of quality management in the Irish manufacturing industry. Measured performance by: (1999)

O’Mara et al.,

1.Operational performance

Performance measures:

(1998).

1. financial performance

M. Y. Ismail, M. El Baradie, and M. S. Quality management in the manufacturing industry: practice vs performance," Computers and J. Hashmi (1998) Industrial Engineering Measured performance by:

1. Quality performance

T. Y. Choi and K. Eboch (1998)

The TQM Paradox: relations among TQM practices, plant performance, and customer satisfaction," Journal of Operations Management Measured performance by:

1.Operation performance

E. E. Adam, L. M. Corbett, B. E. An international study of quality improvement approach and firm performance," Measured Flores et al (1997) performance by:

International Journal of Operations \& Production Management

1.Business performance

K. B.Hendricks andV. R. Singhal, Does implementing an effective TQM program actually improve operating performance? Measured (1997)

performance by:

1.Business performance

J. C. Anderson, M. Rungtusanatham,

R. G. Schroeder, and S.

path analytic model of a theory of quality management underlying the Deming management method: preliminary empirical findings.

1. Quality performance

In addition, Table four summaries the indicators of performance dimensions in oil and gas industry.

Table 4. The indicators of performance dimensions

\begin{tabular}{lll}
\hline Performance Dimensions & Indicators & Reference \\
\hline Indicators of "HSE Performance" & $\begin{array}{l}\text { Number of Safety Incidents which occurred at } \\
\text { drilling location }\end{array}$ & OPAL 2017, IADC 2016, Shell 2018, Tiong \\
Indicators of "Operational & $\begin{array}{l}\text { Percentage of Nonproductive timing against the } \\
\text { threshold }\end{array}$ & Kung Leong 2014 \\
Performance" & &
\end{tabular}

\section{Conceptual Model}

In evaluating the variables that affect company performance, the Partial Least Square Structural Equation Modeling (PLS-SEM) was used, and a conceptual model designed. PLS-SEM is used for causal predictive analysis. This method is nonparametric in nature, which means that this method does not need any supposition concerning the distribution of the data. In addition, PLS-SEM handles a distribution from the data using bootstrapping technique to find out the significance value of path coefficient. The aim of this study is to apply PLS-SEM to better 
understand the ISO9001 objectives which determine its effectiveness and its impact on company performance. The following conceptual model presents the relationship between the six ISO9001 objectives which represents the QMS effectiveness and its overall effect on the performance.

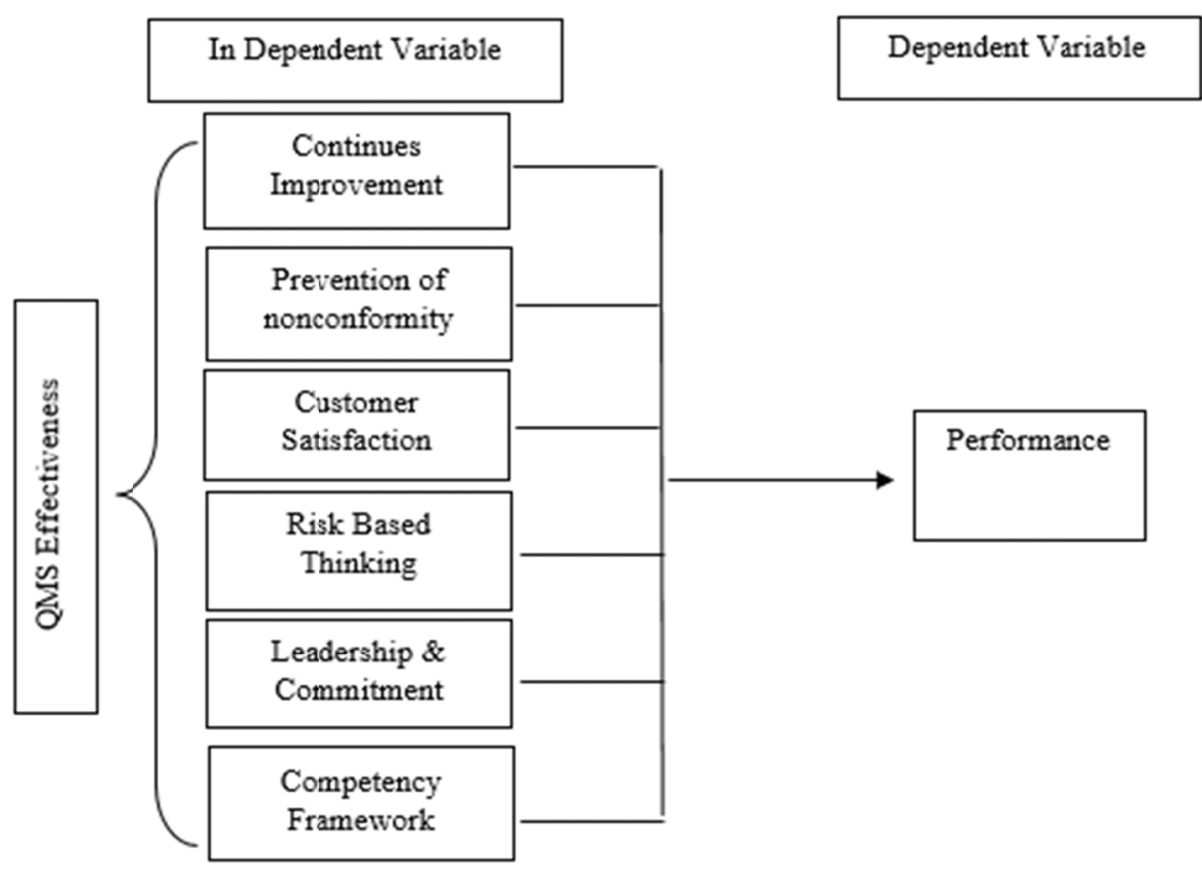

Figure 1. Research conceptual model

\section{Research Methods}

Based on the contradictions presented earlier at the introduction section regarding the significance of ISO 9001 certification on performance and the above review of the literature, the purpose of this present study is in line with many researcher suggestions for future studies which is to evaluate the validity of ISO 9001 QMS effectiveness model and to highlight the impact of ISO 9001 effectiveness on the oil and gas drilling company performance. The twin objectives of this study - evaluate the validity of ISO 9001 QMS Effectiveness model and examine its impact on performance were achieved through a survey based quantitative research method.

\subsection{Questionnaire Design \& Targeted Sample}

Data for the independent variable was collected through a self-administered, 5-point Likert scale questionnaire. The questionnaire method of data collection was best suited for the current study as the respondents were familiar with this instrument and it could be administered to a large sample at relatively additional cost. The absence of the researcher in the data collection process reduced the risk of the researcher's characteristics and demands influencing the responses. The average time to complete the questionnaire was estimated to be twenty minutes so it was acceptable to the managers who might otherwise worry about loss of productive time.

Acquiescent Response Style, Extreme Response Style and Social Desirability Response Style can affect data collected from questionnaires. Podsakoff, MacKenzie, and Lee, (2003) suggested that by protecting the anonymity of the respondents and assuring that there are no correct or incorrect answers acquiescent and socially desirable responses can be reduced. The covering letter to the respondents mentioned that the results will be aggregated and the individual company or respondent will not be identified.

To collect data from the target sample, the researcher approached the CEOs of the respective oil and gas drilling companies and explained the objectives and significance of the study. Anonymity of the respondents, the participating companies and that findings would be reported at an aggregate level was stressed. All the four CEOs consented to participate in the study. Four on shore oil and gas drilling companies coded as $\mathrm{C} 1, \mathrm{C} 2, \mathrm{C} 3$ and $\mathrm{C} 4$ participated in the study resulting in a total population of 2255 employees. Three hundred and seventy-five respondents (C1-129, C2-83, C3-114 and C4-49) were selected using stratified sampling method. According to Barclay, Higgins, and Thompson (1995) the minimum sample size should be 10 times the largest construct. The 
minimum sample requirement 'Thumb Rule of 10' for Structural Equation Modeling was satisfied. 4.8\%, 51.2\% and $44 \%$ of the respondents had the designation of manager, supervisor and operator respectively. $67.2 \%$ and $30.7 \%$ of the respondents were in the age group of 33-47 and 18-32 respectively. As far as experience is concerned, 33.3\% and $58.1 \%$ of the respondents had experience ranging from 1 to 10 and 11-20 years respectively. The above has been visualized in the following figures, figures 2 to 6 .

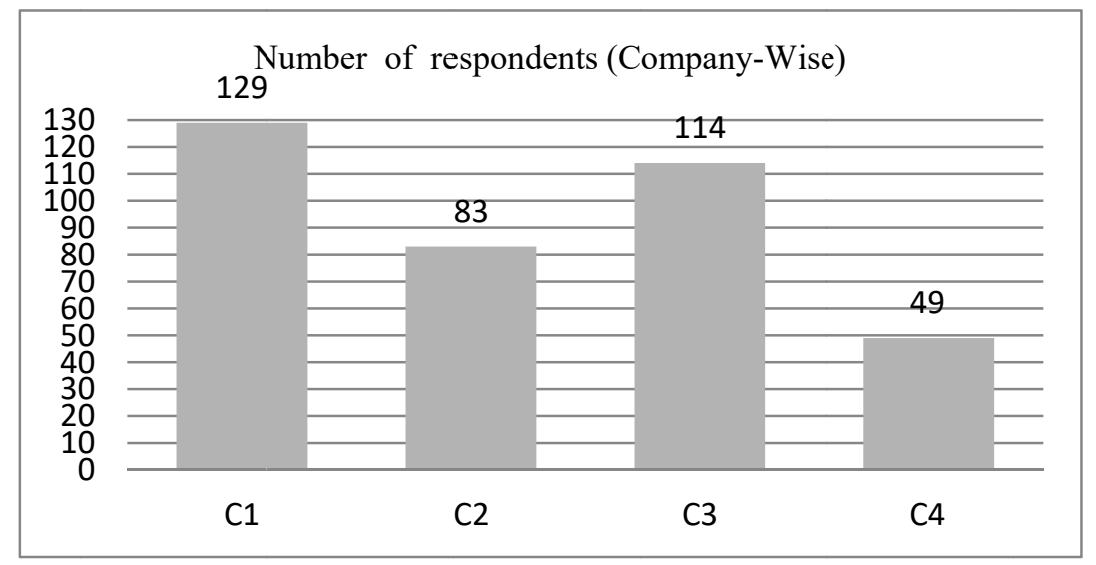

Figure 2. Number of employees participated per company

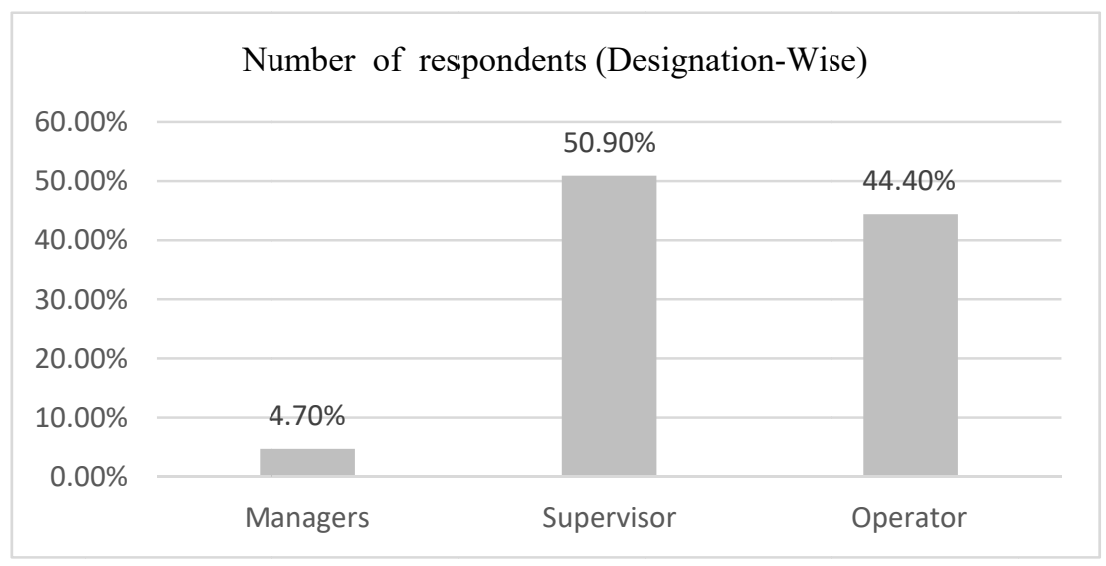

Figure 3. Percentage of employees responds per position

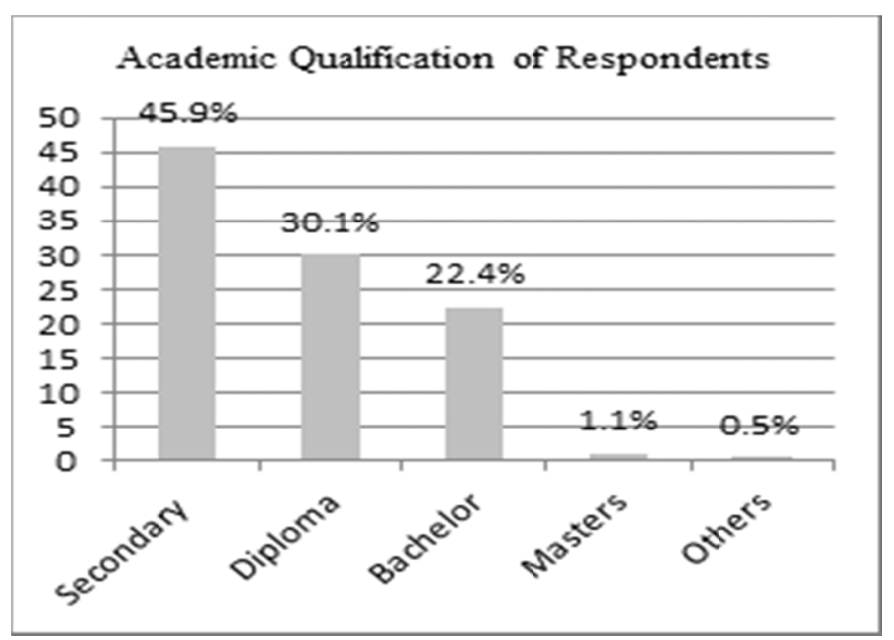

Figure 4. Employees academic percentage 


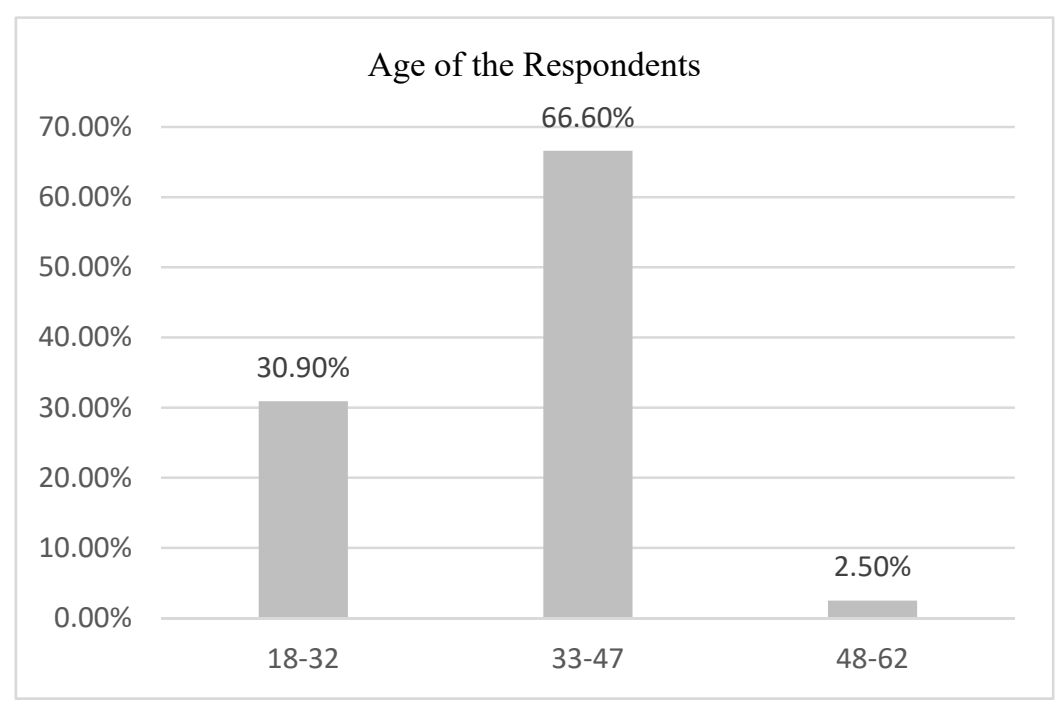

Figure 5. Employees age range percentage

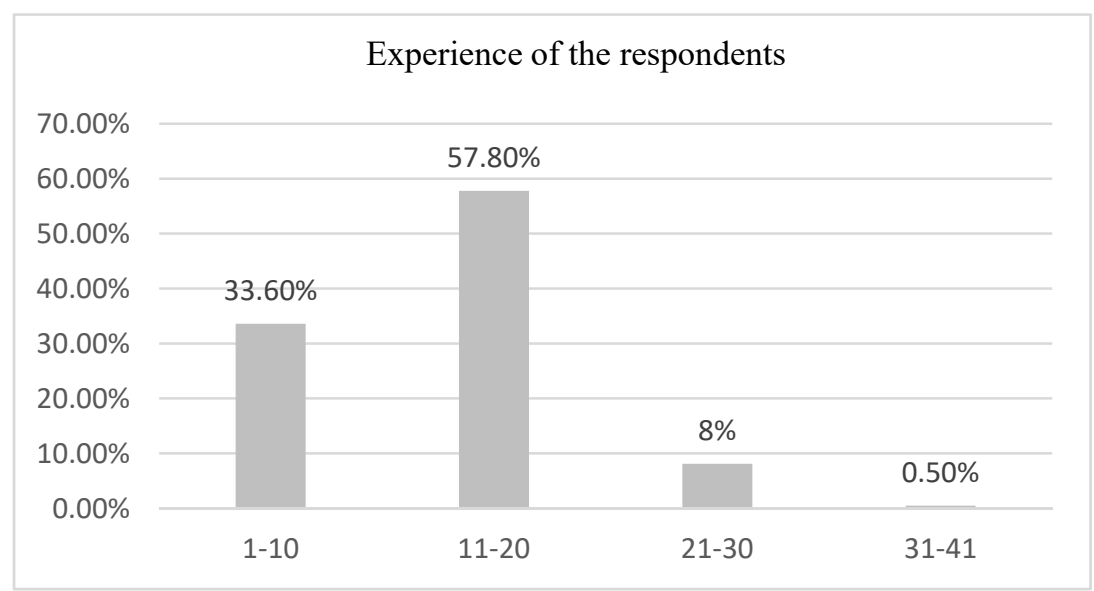

Figure 6. Employees experience range percentage

The questionnaire adopted for the study comprised of two parts- Part A was related to demographic profile and Part B included items on QMS Effectiveness factors in to the performance. The rating scale used was 1-strongly disagree to 5-strongly agree.

The dependent variable, performance of the participating companies, was calculated as the sum of HSE performance and Operational performance. As performance was measured in terms cost, the performance ranking of the firm was reversed ie lower the performance (measured in terms of cost) higher would be the rank.

Primary data was checked for missing values, outliers and un-engaged responses. To get a better understanding of the sample, the relationship between demographic variables (age, experience, educational qualification and designation) and QMS effectiveness was examined using Karl Pearson's co-relation and Analysis of Variance (ANOVA). To get a preliminary idea about the relationship between QMS constructs and performance mean scores of the constructs were calculated for each participating oil and gas drilling company. The proposed model was evaluated through Structural Equation Modeling-Partial Least Squares Method. The Software used for data analysis was Smart PLS Version. The following section discusses the results of the study.

\section{Data Analysis and Results}

\subsection{Demographic Profile and QMS Factors}

The study identified the relationship between the demographic profile of the respondents and QMS factors. A statistically significant relation exists between QMS factors and age, experience, qualification and designation of the respondents. The results are presented in the following table: 
Table 5. Relationship between demographic profile and QMS factors

\begin{tabular}{lllll}
\hline QMS FACTORS & $\begin{array}{l}\text { Age } \\
\mathbf{r}^{\mathbf{a}}\end{array}$ & Experience & $\begin{array}{l}\text { Qualification } \\
\mathbf{F}^{\mathbf{b}}\end{array}$ & Designation \\
\hline Leadership and Commitment & $.309^{* *}$ & $.285^{* *}$ & $12.361^{* *}$ & $10.085^{* *}$ \\
Risk Based Thinking & $.343^{* *}$ & $.332^{* *}$ & $10.326^{* *}$ & $8.847^{* *}$ \\
Competency framework & $.280^{* *}$ & $.293^{* *}$ & $8.114^{* *}$ & $11.620^{* *}$ \\
Prevention of non-conformities & $.343^{* *}$ & $.329^{* *}$ & $5.044^{* *}$ & $9.990^{* *}$ \\
Customer Focus & $.341^{* *}$ & $.336^{* *}$ & $9.147^{* *}$ & $9.544^{* *}$ \\
Continual Improvement & $.289^{* *}$ & $.278^{* *}$ & $14.696^{* *}$ & $10.508^{* *}$ \\
\hline
\end{tabular}

a: Karl Pearson's Coefficient of Correlation; b: F-statistic calculated through ANOVA.

** Correlation is significant at the 0.01 level (2-tailed), Source: SPSS Output.

\subsection{ISO 9001 Objectives and Performance}

The study than compared the mean scores of the factors for the four participating oil and gas companies. C3-the company with the lowest cost had the highest score on all the factors affecting Quality management system. On the other hand, the firm with the highest cost, had comparatively the lowest mean scores across all the dimensions. The findings are reported in the following table:

Table 6. Summary Statistics for Performance and ISO9001 Objectives for the selected Companies

\begin{tabular}{|c|c|c|c|c|c|c|c|}
\hline Company Code & Performance (\$) & $\mathrm{L} \& \mathrm{C}$ & RBT & CFW & $\mathrm{PNC}$ & $\mathrm{CF}$ & $\mathrm{CI}$ \\
\hline $\mathrm{C} 1$ & 394,682 & $\begin{array}{l}3.49 \\
(0.85)\end{array}$ & $\begin{array}{l}3.91 \\
(0.91)\end{array}$ & $\begin{array}{l}3.38 \\
(0.79)\end{array}$ & $\begin{array}{l}3.33 \\
(0.88\end{array}$ & $\begin{array}{l}3.83 \\
(0.92)\end{array}$ & $\begin{array}{l}3.59 \\
(0.73)\end{array}$ \\
\hline $\mathrm{C} 2$ & 179,370 & $\begin{array}{l}4.19 \\
(0.54)\end{array}$ & $\begin{array}{l}4.44 \\
(0.51)\end{array}$ & $\begin{array}{l}4.16 \\
(0.43)\end{array}$ & $\begin{array}{l}4.04 \\
(0.37\end{array}$ & $\begin{array}{l}4.57 \\
(0.48)\end{array}$ & $\begin{array}{l}4.32 \\
(0.40)\end{array}$ \\
\hline $\mathrm{C} 3$ & 169,272 & $\begin{array}{l}4.28 \\
(0.53)\end{array}$ & $\begin{array}{l}4.45 \\
(0.48)\end{array}$ & $\begin{array}{l}4.25 \\
(0.49)\end{array}$ & $\begin{array}{l}4.06 \\
(0.41\end{array}$ & $\begin{array}{l}4.57 \\
(0.47)\end{array}$ & $\begin{array}{l}4.36 \\
(0.42)\end{array}$ \\
\hline $\mathrm{C} 4$ & 668,698 & $\begin{array}{l}3.46 \\
(0.85)\end{array}$ & $\begin{array}{l}3.83 \\
(0.93)\end{array}$ & $\begin{array}{l}3.37 \\
(0.76)\end{array}$ & $\begin{array}{l}3.29 \\
(0.84\end{array}$ & $\begin{array}{l}3.83 \\
(0.89)\end{array}$ & $\begin{array}{l}3.55 \\
(0.72)\end{array}$ \\
\hline Total & NA & $\begin{array}{l}3.88 \\
(0.80)\end{array}$ & $\begin{array}{l}4.18 \\
(0.83)\end{array}$ & $\begin{array}{l}3.82 \\
(0.69)\end{array}$ & $\begin{array}{l}3.70 \\
(0.76\end{array}$ & $\begin{array}{l}4.22 \\
(0.81)\end{array}$ & $\begin{array}{l}3.98 \\
(0.69)\end{array}$ \\
\hline
\end{tabular}

Figures in parentheses () refer to standard deviation.

L\&C: Leadership and Commitment; RBT: Risk Based Thinking; CFW: Competency framework; PNC: Prevention of non-conformities; CF: Customer Focus; CI: Continual Improvement.

Source: SPSS Output.

The relationship between ISO 9001 QMS Effectiveness and performance was examined using Structural Equation Modelling- Partial Least Squares method using Smart PLS Version 3. Although, the results for the measurement and the structural model are estimated simultaneously, we will first discuss the reliability and validity of the measurement model followed by an evaluation of the structural mode.

\subsection{Evaluation of Measurement Model}

The measurement model had seven first order constructs-Leadership and Commitment, Risk Based Thinking, Competency framework, Prevention of non-conformities, Customer Focus, Continual Improvement and the dependent variable Performance. The measurement model was assessed for the reliability of its individual indicators, internal consistency and discriminant validity.

Internal Reliability of the indicators was evaluated using the item loadings and t-statistic. A rule of thumb is to accept an indicator with loading greater than 0.7 and significant t-statistic. The results are presented in the following table: 
Table 7. Convergent validity

\begin{tabular}{|c|c|c|c|}
\hline Construct & Indicators & Outer Loadings & t-statistic \\
\hline \multirow{4}{*}{ Leadership and Commitment } & RA & 0.953 & $94.374 * *$ \\
\hline & PS & 0.964 & $126.289 * *$ \\
\hline & Participation & 0.944 & $102.906^{* *}$ \\
\hline & OS & 0.769 & $13.699 * *$ \\
\hline \multirow{5}{*}{ Risk Based Thinking } & Audits & 0.794 & $24.490^{* *}$ \\
\hline & $\mathrm{EC}(\mathrm{L})$ & 0.963 & $143.245^{* *}$ \\
\hline & $\mathrm{MOC}$ & 0.922 & $48.967^{* *}$ \\
\hline & OI & 0.948 & $103.887 * *$ \\
\hline & RA & 0.925 & $74.702 * *$ \\
\hline \multirow{4}{*}{ Competency framework } & Skills & 0.935 & $83.958 * *$ \\
\hline & $\mathrm{CF}$ & 0.922 & $63.569 * *$ \\
\hline & EA & 0.805 & $24.539^{* *}$ \\
\hline & Coaching & 0.843 & $21.965^{* *}$ \\
\hline \multirow{5}{*}{ Prevention of non-conformities } & $\mathrm{CA}$ & 0.975 & $192.306 * *$ \\
\hline & $\mathrm{QA} / \mathrm{QC}$ & 0.884 & $38.380^{* *}$ \\
\hline & LR & 0.906 & $48.571^{* *}$ \\
\hline & PM & 0.853 & $20.282 * *$ \\
\hline & $\mathrm{PC}$ & 0.966 & $81.111^{* *}$ \\
\hline \multirow{5}{*}{ Customer Focus } & $\mathrm{CF}$ & 0.960 & $126.311^{* *}$ \\
\hline & Define & 0.955 & $117.354 * *$ \\
\hline & $\mathrm{EC}$ & 0.980 & $203.681 * *$ \\
\hline & NU & 0.949 & $66.022 * *$ \\
\hline & $\mathrm{P} \& \mathrm{C}$ & 0.977 & $248.463 * *$ \\
\hline \multirow{5}{*}{ Continual Improvement } & CI Plan & 0.949 & $103.916^{* *}$ \\
\hline & Doc Review & 0.950 & $82.586^{* *}$ \\
\hline & OPID & 0.966 & $145.490 * *$ \\
\hline & PS & 0.955 & $100.620 * *$ \\
\hline & $\mathrm{VM}$ & 0.858 & $16.385^{* *}$ \\
\hline
\end{tabular}

Source: Smart PLS (Version 3) Output.

Loadings on all the constructs were significant and ranged between 0.769 and 0.98 , demonstrating that the data possessed convergent validity.

Reliability is the accuracy or precision with which the indicators measure the corresponding construct. Individual item reliability was assessed using Cronbach's alpha, Rho-A, Composite reliability and Average Variance Extracted. According to Nunnally (1978) [43] for a scale to be considered as reliable, the values of Cronbach alpha should be greater than 0.7 and AVE greater than 0.5 . The reliability results are presented in the following table:

Table 8. Internal consistency of ISO 9001 QMS Objectives

\begin{tabular}{lllll}
\hline ISO9001 objective & $\alpha$ & Rho-A & CR & AVE \\
\hline Leadership and Commitment & 0.918 & 0.946 & 0.951 & 0.83 \\
Risk Based Thinking & 0.920 & 0.959 & 0.961 & 0.832 \\
Competency framework & 0.981 & 0.982 & 0.985 & 0.93 \\
Prevention of non-conformities & 0.756 & 0.956 & 0.964 & 0.843 \\
Customer Focus & 0.981 & 0.982 & 0.985 & 0.93 \\
Continual Improvement & 0.943 & 0.967 & 0.973 & 0.877 \\
Performance & 0.885 & 0.885 & 0.946 & 0.897 \\
\hline
\end{tabular}

$\alpha$ : Cronbach's Alpha; CR: Composite Reliability; AVE: Average variance extracted.

Source: Smart PLS (Version 3) Output.

Each of the construct in the proposed model had values of cronbachs alpha, rho A and composite reliability above the threshold limit of 0.7 and AVE above 0.5 establishing the reliability of the constructs. 
Discriminant validity of a construct is a measure of how distinct the construct is from other latent variables. The study used the Fornell-Larcker Criterion to assess the discriminant validity of the constructs.

Table 9. Discriminant Validity of ISO 9001 QMS Objectives

\begin{tabular}{lllllll}
\hline & CFW & CI & CF & L\&C & PNC & RBT \\
\hline Competency framework & 0.895 & & & & & \\
Continual Improvement & 0.838 & 0.936 & & & & \\
Customer Focus & 0.862 & 0.91 & 0.964 & & & \\
Leadership and Commitment & 0.836 & 0.895 & 0.901 & 0.911 & & \\
Prevention of non-conformities & 0.884 & 0.93 & 0.93 & 0.901 & 0.918 & \\
Risk Based Thinking & 0.833 & 0.897 & 0.907 & 0.907 & 0.905 & 0.912 \\
\hline
\end{tabular}

Source: Smart PLS (Version 3) Output.

In the above table the square roots of AVE (the diagonal items) are presented in bold. The off-diagonal items are the inter item correlations. For the scale to possess discriminant validity, the off-diagonal items should be lower than the diagonal items. According to the Fornell Larcker criterion, it can be concluded that the constructs possessed discriminant validity.

After ascertaining that the measurement model was reliable and valid, the study than evaluated the structural model.

\subsection{Structural Model}

\subsubsection{Measuring the Value of $\mathrm{R}^{2}$}

The structural model is evaluated based on $\mathrm{R}^{2}$, path coefficient $\beta$ and its statistical significance, Effect Size $\mathrm{f}^{2}$ and $\mathrm{Q}^{2}$. The coefficient of determination tells the amount of variation in the construct can be explained by the model. The $\mathrm{R}^{2}$ value for the first order constructs are all above the 0.7 , implying that the six constructs significantly explain the second order construct ISO 9001 QMS effectiveness. The $\mathrm{R}^{2}$ for QMS effectiveness is 0.460 . In the current study, $46 \%$ of the variation in performance can be explained by effective quality management systems.

\subsubsection{Measuring the Effect Size $\mathrm{f}^{2}$}

The effect size $\mathrm{f}^{2}$ was calculated to assess the effect each latent construct has on Quality Management Systems. An effect size between 5 and $15 \%$ is considered moderate and greater than $15 \%$ as a strong effect. The $\mathrm{f}^{2}$ values are tabulated as follows:

Table 10. Effect size

Source: Smart PLS (Version 3) Output.

\begin{tabular}{lll}
\hline Construct & $\mathrm{F}^{2}$ & Inference \\
\hline CFW & 16.607 & Moderate \\
CI & 26.042 & Moderate \\
CF & 23.023 & Moderate \\
L\&C & 24.264 & Moderate \\
PNC & 35.92 & High \\
RBT & 25.271 & Moderate \\
\hline
\end{tabular}

\subsubsection{Estimation of path coefficient $(\beta)$ and T-statistics}

The Beta value and its statistical significance was assessed through boot-strapping. The results of path analysis are summarized in the following table: 
Table 11. Summary of paths

\begin{tabular}{|c|c|c|c|}
\hline Paths & Expected Sign & $\begin{array}{l}\text { Path } \\
\text { Coefficient }\end{array}$ & t-value \\
\hline Leadership and Commitment is a first order construct of ISO 9001 QMS Effectiveness & + & 0.953 & $108.695 * *$ \\
\hline Risk Based Thinking is a first order construct of ISO 9001 QMS Effectiveness & + & 0.949 & $110.340 * *$ \\
\hline Competency framework is a first order construct of ISO 9001 QMS Effectiveness & + & 0.920 & $72.139 * *$ \\
\hline Prevention of non-conformities is a first order construct of ISO 9001 QMS Effectiveness & + & 0.973 & $161.600 * *$ \\
\hline Customer Focus is a first order construct of ISO 9001 QMS Effectiveness & + & 0.962 & $88.237 * *$ \\
\hline Continual Improvement is a first order construct of ISO 9001 QMS Effectiveness & + & 0.957 & $0.957 * *$ \\
\hline ISO9001 QMS effectiveness $\longrightarrow$ Performance & - & -0.678 & $12.646^{* *}$ \\
\hline
\end{tabular}

Source: Smart PLS (Version 3) Output.

From the above table, a higher order construct ISO 9001 QMS effectiveness with six constructs- Leadership and Commitment, Risk Based Thinking, Competency Framework, Prevention of Non-Conformities, Customer Focus and Continual Improvement was validated. A statistically significant negative relationship between ISO 9001 QMS Effectiveness and performance exists.

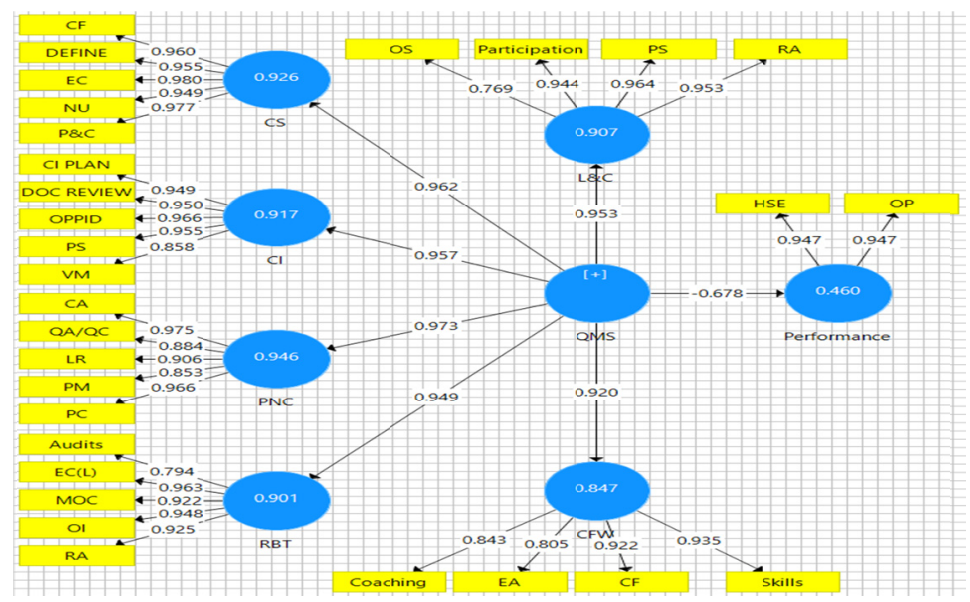

Figure 7. Relationship between QMS ISO 9001 Effectiveness and Performance, Source: Smart PLS (Version 3) Output, Inner Model: Path Coefficients; Outer Model: Loadings; Constructs: R2.

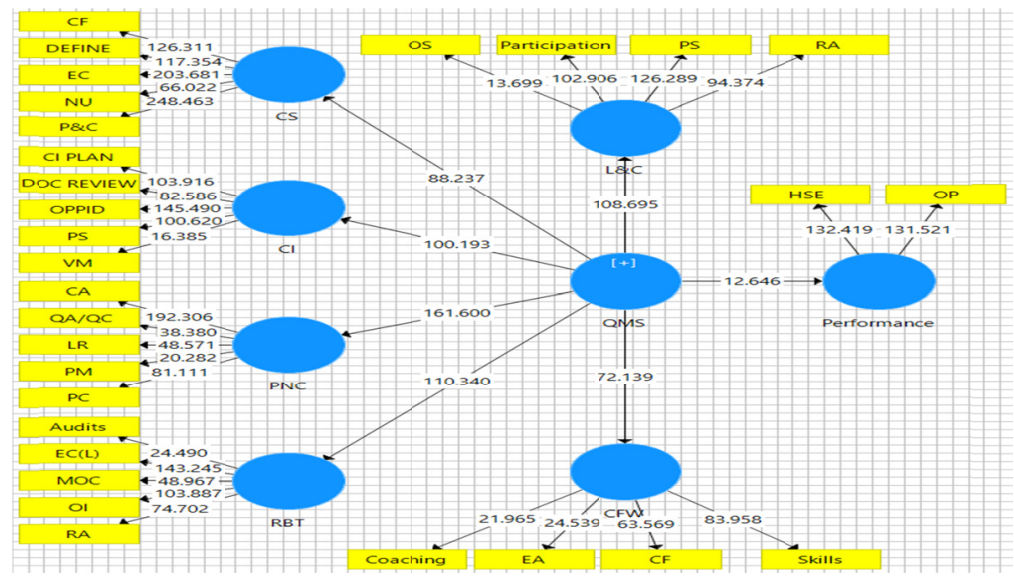

Figure 8. PLS - SEM ISO 9001 QMS effectiveness model (After Bootstrapping), Source: Smart PLS (Version 3) Output

\subsubsection{Predictive Relevance of the $\operatorname{Model}\left(\mathrm{Q}^{2}\right)$}

Q SQUARE values predict effect of ivs and dv. Using the below table, effect size is high. From the Q square 
statistic, it is inferred that QMS 9001 effectiveness has a high (strong) effect of $39 \%$ on performance as demonstrated in below table.

Table 12. Q2 value for this study

\begin{tabular}{llll}
\hline & SSO & SSE & $\mathrm{Q}^{2}(=1-\mathrm{SSE})$ \\
\hline Performance & 198 & 119.251 & 0.398 \\
\hline
\end{tabular}

\subsubsection{The Standardized Root Mean Square Residual (SRMR)}

Model fit was assessed based on the SRMR criteria. If SRMR is less than 0.08 , the model is said to have a good fit. The results presented in the following table indicate that the empirical data fits the model.

Table 13. SRMR value for this study

\begin{tabular}{lll}
\hline & Saturated Model & Estimated Model \\
\hline SRMR & 0.052 & 0.054 \\
\hline
\end{tabular}

\section{Discussion}

This study has contributed to evaluate the validity of ISO 9001 QMS effectiveness model and to highlight the impact of ISO 9001 effectiveness on the oil and gas drilling company performance operating in OMAN using SMART-PLS technique.

The results of the study revealed that the six ISO objectives namely L\&C, PNC, CI, RBT, CF and CFW have a significantly positive effect on QMS effectiveness $\left(\mathrm{R}^{2}=0.460, \mathrm{p}=0.000\right)$, predictive relevance $\left(\mathrm{Q}^{2}=0.398\right)$ and Standardized Root Mean Square Residual (SRMR=0.052).

The final SEM results revealed that the prevention of non-conformity factor had the highest effect size $\left(\mathrm{f}^{2}=\right.$ $35.92 \%$ ). Therefore, the oil and gas drilling companies should pay more attention to prevention non-conformity related factors to improve the effectiveness of their quality management system which will be reflected in their performance. The remaining objectives have moderate effect on QMS effectiveness ranked as follow: CI and RBT values are $\left(\mathrm{f}^{2}=26.042 \%, \mathrm{f}^{2}=25.271 \%\right.$ ) which are coming under PNC and this gives clear indication for oil and gas companies to focus more on the risk-based approach in a continual improvement manner. Remaining objectives are $\mathrm{L} \& \mathrm{C}$ and $\mathrm{CF}$ with values of $\left(\mathrm{f}^{2}=24.264 \%, \mathrm{f}^{2}=23.023 \%\right.$ respectively) and the least score was with the CFW ( $\left.\mathrm{f}^{2}=16.607 \%\right)$. The findings of this study showed that QMS effectiveness is defined as the extent to which the anticipated objectives are met and these objectives are: L\&C, PNC, CI, RBT, CF and CFW.

Leadership and commitment is one of the defined objectives to achieve the effectiveness of QMS. This correlate with Kumar, 2012 who claim that leadership and commitment from top management will promote a positive organizational culture that is capable to lead, own and support QMS actions among employee from different level of the organization. It was further indicated in table 2 and 7 that although four sub-elements are influencing leadership and commitment namely policy statement \& objective set up, participation \& involvement, organization structure set up and resource allocation. However, policy statement \& objective set up is having the highest impact on leadership \& commitment in Oman oil and gas drilling companies followed by resource allocation which means that oil and gas companies need to focus more on simplifying their polices and ensuring that the objectives are clearly set to the workforce.

Customer focus is considered to be another objective which defines the effectiveness of QMS. This is in-line with the results of Dahlgaard (2013) who claimed that total quality management implemented through QMS is an evolving system of practices, tools and training methods for managing organizations to provide and results into customer satisfaction in a rapidly changing world. It was further indicated in table 2 and 7 that although five sub-elements are influencing customer focus namely defining customers including interested parties, understanding customer needs, measuring customer feedback, controls including recovery plan to address customer needs and establishing effective communication. However, effective communication is having the highest impact on customer focus in Oman oil and gas drilling companies followed by controls including recovery plan to address customer needs. This was evident among the 4 companies selected for this research by which the best performing company among the four did focus more and scored the highest in the customer satisfaction as 
indicated in table 7.

Prevention of non-conformity is considered to be another objective which defines the effectiveness of QMS. Duke Okes (2017) concluded a positive influence of sustaining corrective actions to eliminate non conformity on the overall performance through a study on root cause analysis. It was further indicated in table 2 and 7 that although five sub-elements are influencing prevention of non-conformity namely process conformity, establishing an effective quality assurance/ quality control system (QA/QC), preventative maintenance, deliver of corrective actions which shall be part of the recovery plan and ensure complying with legal and contracts requirements in Oman oil and gas drilling companies. However, deliver of corrective actions is having the highest impact on prevention of non-conformity followed by process conformity. Oil and gas companies shall focus on this element as process non conformity will lead to NPT which is considered to be one of performance diminutions in oil and gas industry.

Risk based thinking is considered to be another objective which defines the effectiveness of QMS. This correlate with the new version of ISO 9001:2015 standard, which states that risk-based thinking is considered to be one of the main objectives of the QMS and a key requirement for verifying the effectiveness of ISO 9001. In addition, Risk-based thinking enables an organization to determine the factors that could cause its processes and its quality management system to deviate from the planned results, to put in place preventive controls to minimize negative effects and to make maximum use of opportunities as they arise and enhance the overall performance. It was further indicated in table 2 and 7 that although five sub-elements are influencing risk-based thinking namely risk assessment, audits at different levels, management of change, effective communication of learnings and opportunities identification in Oman oil and gas drilling companies. However, effective communication is having the highest impact on risk-based thinking followed by opportunities identification. Oil and gas drilling rigs are associated with many risky activities by which companies shall really focus on this seriously, otherwise a catastrophic disaster might happen. This was evidence after the major blow out accident which occurred in Gulf Mexico in 2010 by which one of the drilling rigs got blow out ending up with eleven fatalities and billions of dollars including reputation was lost. Hence, promoting the risk-based approach was one of the objectives in the newly released version of ISO9001:2015 and the released API Q1 \& Q2 risk-based standards specifically for oil and gas sector. Oil and gas companies who did not yet obtain this approach shall have a structured plan to obtain this culture.

Continual improvement is considered to be another objective which defines the effectiveness of QMS. This is in-line with Zeng, 2007 who confirmed that continual improvement is considered to be vital element in achievement of expectations and overcoming barriers to implementation of the dynamic QMS systems. It was further indicated in table 2 and 7 that although five sub-elements are influencing continual improvement namely developing of CI business plan, process of documentation review and update, process simplicity, visual management and improvement ideas under the theme of opportunity identification in Oman oil and gas drilling companies. However, improvement ideas are having the highest impact on continual improvement followed by process simplicity.

Competency framework is considered to be another objective which defines the effectiveness of QMS. This confirms to Mangal (2009) who claimed that competency frame work is a planned process to modify attitude, knowledge, skills or behavior through learning experience to achieve effective performance in an activity or range of activities. It was further indicated that although four sub-elements are influencing competency frame work namely skills and training, coaching, awareness and establishing a competency frame work related to drilling activities in Oman oil and gas drilling companies. However, skills and training is having the highest impact on competency frame work followed by establishing a fit for purpose drilling competency frame work.

As shown in Table 7, a higher order construct ISO 9001 QMS effectiveness with six constructs- Leadership and Commitment, Risk Based Thinking, Competency Framework, Prevention of Non-Conformities, Customer Focus and Continual Improvement was validated. A statistically significant negative relationship between ISO 9001 QMS Effectiveness and performance exists, as the performance dimensions in oil and gas industry are measured through cost by which the less the cost (which will indicate less HSE and NPT), the better the performance will be.

\section{Conclusion}

The present study contributes to the existing body of literature by investigating the effects of ISO 9001 effectiveness on oil and gas drilling companies' performance. However, the major point that differentiates the present study from similar studies concerns the fact that ISO 9001 effectiveness is introduced here and assessed by definition through the degree of achievement of the ISO 9001 objectives in oil and gas industry and moving 
from process based approach to risk based approach, namely leadership and commitment, competency framework, risk based thinking, continuous improvement, customer satisfaction focus and prevention of nonconformities. It is also worth noting that, while ISO 9001 effectiveness has been widely mentioned in the literature as a significant parameter of quality management and company performance, no studies, to the best of authors' knowledge, use these ISO 9001 objectives and their indicators using the newly released version in order to assess ISO 9001 effectiveness in oil and gas companies. According to the study findings, by achieving the ISO 9001 objectives (in other words by increasing ISO 9001 effectiveness), the company's performance will be improved.

\section{Patent \& Copyrights}

The conceptual model which has been developed in this research and validated using the SEM-PLS model is a patent. Copyright for this article is retained by the author, with first publication rights granted to the journal. This is an open-access article distributed under the terms and conditions of the Creative Commons Attribution license (http://creativecommons.org/licenses/by/4.0/).

\section{References}

Ahmed. (2016). Impact of Leadership and Training on performance of service companies.

Al-Nakeeb, A. R., Williams, T., Hibberd, P., \& Gronow, S. (1998). Measuring the effectiveness of quality assurance systems in the construction industry. Property Management Journal, 16(4), 222-228.

Augustyn, M. M., \& Pheby, J. D. (2000). ISO 9000 and performance of small tourism enterprises: a focus on Westons Cider Company. Managing Service Quality, 10(6), 374-388. https://doi.org/10.1108/09604520010351194

Barclay, D., Higgins, C., \& Thompson, R. (1995). The Partial Least Squares (PLS) Approach to Causal Modelling: Personal Computer Adoption and Use as an Illustration. Technology Studies, Special Issue on Research Methodology, 2(2), 285-309.

BP2015. (2015). Business pan 2015. Muscat: BP Company.

Bravi, F. M., \& Laura. (2017). Empirical evidence about ISO 9001 and ISO 9004 in Italian companies. The TQM Journal, 29(5), 650-665. https://doi.org/10.1108/TQM-11-2016-0097

Chris. (2017). Oil and Gas Business objectives. Muscat: s.n.

Company X. (2014), Oil and gas performance annual report measurements. https://doi.org/10.1108/02637479810243437

Contracting. (2017). Contract Document (6th ed.). Muscat: s.n.

Dick, G., Gallimore, K., \& Brown, J. C. (2001). ISO 9000 and quality emphasis: an empirical study of front-room versus back-room dominant service industries. International Journal of Service Industry Management, 12(2), 114-136. https://doi.org/10.1108/09564230110387498

Donwa, P. A. (2015). Economic Growth: Oil and Gas Contributions. Sci-Afric Research Journal of Accounting and Monetary Policy, 1(2), 102-108.

Evangelos, L. P. (2012). The impact of ISO 9001 effectiveness on the performance of service companies. Managing Service Quality: An International Journal, 23(2), 149-164. https://doi.org/10.1108/09604521311303426

Gomez-Gomez, J., Martinez-Costa, M., \& Martinez-Lorente, A. R. (2011). A critical evaluation of EFQM model. International Journal of Quality Reliability Management, 28(5), 484-502. https://doi.org/10.1108/02656711111132544

Gotzamani, T. G., Nicolaou, M., Nicolaides, A., \& Hadjiadamou, V. (2007). The contribution to excellence of ISO 9001: the case of certified organizations in Cyprus. The TQM Magazine, 19(5), 388-402. https://doi.org/10.1108/09544780710817838

Heras, S., Landin, G., \& Fa, M. (2006). A Delphi study on motivation for ISO 9000 and EFQM. International Journal of Quality and Reliability Management, $23(7), \quad 807-827$. https://doi.org/10.1108/02656710610679824

IADC. (2015). IADC Drilling Manual. USA: IADC.

IADC. (2016). Oil and gas Key performance indicators. 
ISO 9001:2000. (2000). Quality Management Systems-Requirements, Hellenic Body for Standardization (ELOT), Athens.

ISO 9001:2008. (2008). Quality Management Systems-Requirements. Hellenic Body for Standardization (ELOT), Athens.

ISO9001:2015. (2015). Quality management principles, 2015, ISO, Geneva.

Jain, S. K. (2012). An evaluation of ISO 9000 initiatives in Indian industry for enhanced manufacturing performance. International Journal of Productivity and Performance Management, 61(7), 778-804. https://doi.org/10.1108/17410401211263863

Jang, W., \& Lin, C. (2008). An integrated framework for ISO 9000 motivation, depth of ISO implementation and firm performance. Journal of Manufacturing Technology Management, 19(2), 194-216. https://doi.org/10.1108/17410380810847918

Karapetrovic, S., \& Willborn, W. (1998). Connecting internal management systems in service organizations. Managing Service Quality, 8(4), 256-71. https://doi.org/10.1108/09604529810222550

Lee, P. K. C., To, W. M., \& Yu, B. T. W. (2009). The implementation and performance outcomes of ISO 9000 in service organizations: An empirical taxonomy. International Journal of Quality and Reliability Management, 26(7), 646-62. https://doi.org/10.1108/02656710910975732

Lee, P. K. C., To, W. M., \& Yu, B. T. W. (2009). The implementation and performance outcomes of ISO 9000 in service organizations: An empirical taxonomy. International Journal of Quality and Reliability Management, 26(7), 646-662. https://doi.org/10.1108/02656710910975732

Lee, P. K. C., To, W. M., \& Yu, B. T. W. (2009). The implementation and performance outcomes of ISO 9000 in service organizations: an empirical taxonomy. International Journal of Quality and Reliability Management, 26(7), 646-662. https://doi.org/10.1108/02656710910975732

Marin, L. M., \& Ruiz-Olalla, M. C. (2011). ISO 9000:2000 certification and business results. International Journal of Quality \& Reliability Management, 28(6), 649-661. https://doi.org/10.1108/02656711111141201

Nunnally, J. C. (1978). Psychometric Theory. New York: McGraw-Hill.

Perrons, R. K. (2013). Cloud computing in the upstream oil \& gas industry: A proposed way forward. Energy Policy, 56, 732-737. https://doi.org/10.1016/j.enpol.2013.01.016

Podsakoff, P. M., MacKenzie, S. B., \& Lee, J. Y. (2003). Common Method Biases in Behavioral Research: A Critical Review of the Literature and Recommended Remedies. Journal of Applied Psychology, 88(5), 879-905. https://doi.org/10.1037/0021-9010.88.5.879

Posmas, E. L. (2013). The impact of ISO 9001 effectiveness on the performance of service companies. Managing service quality: An International Journal, 23(2), 149-164. https://doi.org/10.1108/09604521311303426

Psomas, E., Fotopoulos, C., \& Kafetzopoulos, D. (2010). Critical factors for effective implementation of ISO 9001 in SME service companies. Managing Service Quality, 20(5), 440-457. https://doi.org/10.1108/09604521011073731

Psomas, E., Kafetzopoulos, D., \& Fotopoulos, C. (2013). Developing and validating a measurement instrument of ISO 9001 effectiveness in food manufacturing SMEs. Journal of Manufacturing Technology Management, 24(1), 52-77. https://doi.org/10.1108/17410381311287481

Robinson, D. L. (2015). Drilling Knowledge Book (1st ed.). NY: IADC.

Sampaio, P., Saraiva, P., \&Rodrigues, A. G. (2009). ISO 9001 certification research: questions, answers and approaches. International Journal of Quality and Reliability Management, 26(1), 38-58.

Spiegel, M., Luning, P., Ziggers, G. and Jongen, W. (2004). Evaluation of performance measurement instruments on their use for food quality systems. Critical Reviews in Food Science and Nutrition, 44(7), 501-12. https://doi.org/10.1080/10408690490489350

To, W. M., Lee, P. K. C., \& Yu, B. T. W. (2011). ISO 9001:2000 implementation in the public sector: a survey in Macao SAR, the People's Republic of China. The TQM Journal, 23(1), 59-72. https://doi.org/10.1108/17542731111097498

Todorut. (2013). Factors affecting overall performance in construction industry. 
Umar. (2004). Relationship between leadership and performance.

Van der Spiegel, M., Boer, W., Luningy, P., Ziggers, G., \& Jongen, W. (2007). Validation of the instrument IMAQE-food to measure effectiveness of food quality management. International Journal of Quality \& Reliability Management, 24(4), 386-403. https://doi.org/10.1108/02656710910924161

Wahid, R. A., \& Corner, J. (2009). Critical success factors and problems in ISO 9000 maintenance.International Journal of Quality and Reliability Management, 26(9), 881-893. https://doi.org/10.1108/02656710910995073

Yaya, L. H. P., Marimon, F., \& Casadesus, M. (2011). Customer's loyalty and perception of ISO 9001 in online banking. Industrial Management and Data Systems, 111(8), 1194-213. https://doi.org/10.1108/02635571111170767

Zwain. (2012). Influence of Leadership and Competency on the performance.

\section{Copyrights}

Copyright for this article is retained by the author(s), with first publication rights granted to the journal.

This is an open-access article distributed under the terms and conditions of the Creative Commons Attribution license (http://creativecommons.org/licenses/by/4.0/). 